\title{
Gendered political capital resources: The case of party office
}

\author{
Tània Verge and Sílvia Claveria
}

\section{Introduction}

Party patronage, whose scope and reach varies significantly across countries, can be conceived of as a "key mechanism of elite recruitment" through which political parties are able to control policy design and implementation. Partisan loyalties allow minimizing preference divergence between the principal - the recruiter - and the agent - the appointee (Kopecký and Mair, 2012: 12; see also Müller, 2006). Political parties are the gatekeepers of legislative office, with the candidate pool being largely made of party members (Gallagher and Marsh, 1988). Party patronage also reaches cabinet appointments. Prime ministers and presidents tend to be the party leaders and heavy weights of the party usually occupy prominent positions within the government thereby leading to the fusion of party and ministerial elites (Blondel, 2000; Warwick and Druckman, 2001). Parties can also make appointments to the top echelons of the public administration, to advisory and regulatory public bodies, and to the governing boards of public or recently privatized companies (Kopecký and Mair, 2012: 13), which facilitates ex-ministers' post-office political career (Claveria and Verge, 2015).

Party membership and especially party office can thus be characterized as a political capital or "organizational" resource that provides individuals with privileged access to the patronage parties can distribute (Kopecký and Mair, 2012: 3). Yet, we cannot assume that the benefits carried by party office will benefit all individuals holding it. As argued by AUTHOR (2016a), individuals operating within political parties are not disembodied actors and gender power relationships underpin the recruitment of the political elite, one of the main functions of political parties. The historical relative exclusion of women has structured party politics around malecentered practices and produced several instances of overt or indirect discrimination against women (Lovenduski, 2005: 48-53). As Verge (2015: 758) argues, "the individual meeting the 'ideal' party member traits, behavior and participation 
repertoires that provide more credentials in the recruitment process is by definition a man - the man" (emphasis in the original).

The gendered access to resources, opportunities and recognition within parties (Verge and de la Fuente, 2014) warrants serious attention for the evaluation of internal party democracy (Childs, 2013). We can ask then, is leverage gained by women in political recruitment processes when party office is held? In this article, while measuring the extent to which party office is a political capital resource, we also investigate whether the benefits carried by it are distributed equally across sex. We hypothesize that party office is a gendered political capital resource - i.e. it is more likely to benefit men's ascendant political careers. To test this expectation we undertake a cross-national analysis of political recruitment in advanced industrial democracies.

We concentrate on candidacy for legislative office, ministerial appointments and the post-ministerial offices in public and semi-public life that are in the hands of political parties to distribute.

Our comparative analysis shows that party office produces heterogeneous effects across sex since it is mostly instrumental for men's political advancement. This result holds when controlling for other political capital resources, sociodemographic factors and country-level variables. The remainder of the article is organized as follows. After developing our theoretical framework and presenting the hypotheses, we describe the data and method used in our survey of recruitment processes. Next, we discuss the results of the empirical analysis. Lastly, we conclude and suggest several avenues for further research.

\section{Literature review}

The masculine ethos of political parties is still well reflected in the composition of the party membership. Despite increasing levels of female members, in advanced industrial democracies, men still account, on average, for two thirds of the rank and file (Scarrow and Gezgor, 2010: 831). Masculinization also prevails in parties' decision-making bodies, which has strong implications for political recruitment. Besides acting as role models for female citizens and pushing for women's interests in party policies, female party officers have been found to promote the nomination of more women candidates. The in-group effect through which party gatekeepers tend to select candidates that 
resemble them and resort to predominantly male networks is mitigated when the composition of the selectorate is more gender balanced (Cheng and Tavits, 2011; Kittilson, 2006; Kunovich and Paxton, 2005; Niven, 1998).

Comparative studies indicate that women hold, on average, about $30 \%$ of senior party offices, with higher percentages found in parties using internal sex quotas (Kittilson, 2006: 42). However, women's progress in party executives is still "a contested, slow, uneven, and incomplete process" (Kittilson, 2013: 546). By occupying senior positions within political parties women may have been "included but not integrated, that is, lacking substantive power" (Childs, 2013: 93). To begin with, men make for about $90 \%$ of party leaders selected since the 1960s (Wauters and Pilet, 2015). Women's absence in this position is especially strong among the largest parties (Bashevkin, 2010). Other studies show that female party leaders are often elected in contexts of poor party popularity (Trimble and Arscott, 2003: 71), their tenure is more contested and present higher turnover rates than men (O'Brien, 2015; O'Neill and Steward, 2009).

Other discriminatory experiences include the gendered distribution of top party offices (Jennings and Farah, 1981; Verge, 2015), with women assuming more frequently labor intensive roles or routine functions rather than more visible and socially recognized roles (Fowlkes, Perkins and Tolleson-Rinehart, 1979). Also, party committees headed by women usually have significantly smaller budgets than those headed by men, forcing women to "do more with less" (Shea and Harris, 2006: 73-74). On the other hand, female party officers are frequently held to higher standards, face continuous super-surveillance and receive scarce recognition for their work. This yields an asymmetric disposition of resources, visibility and influence that sustains a gender power imbalance (Verge and de la Fuente, 2014: 72).

The vertical segregation of party offices - with high-ranked positions being fielded typically with men - further deepens women's disadvantage. Indeed, positions on electoral lists reflect candidates' prominence within the party hierarchy (Franceschet and Piscopo, 2014: 96). As posited by Threlfall (2005: 137), "the composition of the constituency candidate lists, being the nexus between internal party life and public office, reflects the overall gender balance of power throughout a party" (see also AUTHOR, 2016b). Simultaneously, top-ranked candidates in party lists are typically 
awarded the most desirable positions in the local party executive (O'Brien and Rickne, 2014: 15). Therefore, monopolizing the positions at the top of the lists is not only instrumental to securing election but also to maintaining positional power within parties (Childs and Rainbow, 2014: 81). Thus, our first hypothesis posits that:

\section{H1: Holding party office benefits men more than women as regards access to} viable candidacy.

Concerning cabinet appointments, as Annesley and Gains (2010: 915) suggest, "aspirant ministers also need to be loyal to the party leadership and prime minister, play the favours game and be well networked". Regional and national party leadership positions have been found to be the main recruiting field for ministers. However, most of the women in regional party executives do not get a policy portfolio but are brought in as lower-tier junior members (Threlfall, 2005: 132). Those who get a portfolio tend to be appointed to a 'soft' or 'feminised' policy area like social welfare, environment, social movements, education and culture or youth, which are considered to be second order positions of power. This creates a horizontal segregation within the party leadership wherein men populate the positions more likely to pave the way to ascendant political careers - like organisation or finances (Verge and de la Fuente, 2014: 72).

On the other hand, while appointees' credentials are relevant, a widespread "tradition" mandates that some "ministers are drawn from the party leadership" (Franceschet and Thomas, 2015: 651). Presidents and prime ministers "want certain "chemistry"' in their government (Borrelli, 2002: 5). As highlighted by Annesley (2015: 632), "there is evidence that women are excluded - either overtly or covertly - from the crucial networks around the prime minister that set up opportunities for ministerial office". In parliamentary systems, for men there is a positive association between integrating the party 'shadow cabinet' - whose members are appointed by the leader of the main opposition party (typically the party leader) to mark members of the cabinet and occupying prestigious portfolios within the government when the party wins the election (Karam and Lovenduski, 2005: 200). Likewise, in presidential systems, "party insider" presidents tend to appoint fewer women to their cabinet than "free-wheeling independent" presidents (Escobar-Lemmon and Taylor-Robinson, 2008: 362). 
Furthermore, connections to the president increase the chances of being appointed to a prestigious portfolio exclusively in the case of men (Escobar-Lemmon and TaylorRobinson, 2014). In this light, our second set of hypotheses sustains that:

H2.1: Holding party office benefits men more than women as regards access to ministerial office.

H2.2: Holding party office benefits men more than women as regards access to prestigious cabinet portfolios.

Lastly, post-ministerial occupation can be considered another type of recruitment (Nicholls, 1991). Whereas women present higher turnover rates in public office than men (Verge and de la Fuente, 2014: 74; see also O'Neill and Steward, 2009), female and male senior officials who have made it to the apex of national politics might well have similar levels of ambition to pursue other positions in the political arena or in other fields. As shown by Claveria and Verge (2015:9) women do not return to their previous job at significantly higher rates than men upon cabinet termination and take up positions in private business (i.e. corporate boards) at similar rates. The postministerial occupations that present larger (although non statistically significant) gender differences are moving to another position in politics, where more men are found, and landing in international organizations or assuming leading roles in advocacy networks, where more women are found. Whereas parties' influence on the international arena is rather limited, the political field is clearly shaped by parties. Accordingly, our third and last hypothesis posits that:

H3: Holding party office benefits men more than women as regards access to new political positions once cabinet service ends.

\section{Data and methods}

Given that we are interested in parties' role in political recruitment processes our study is restricted to countries with strong political parties. We cover polities from North America, Europe and Australasia. Our data comes from various sources. In examining 
candidacy to legislative office we use the Comparative Candidate Survey database (CCS, 2014). It includes information on candidates to the national parliament in several democracies. The countries with available data on party office for candidates competing in the most recent election are Belgium, Czech Republic, Denmark, Finland, Germany, Greece, Hungary, Netherlands, Norway, Portugal, Sweden and Switzerland. Among these twelve countries, women account, on average, for $35.5 \%$ of candidates.

To explore the gender distribution of executive and post-ministerial positions we use Claveria's (2014a) cross-national database, which contains information on ministers' profiles and routes to executive office (before being appointed as minister), portfolio allocation (once appointed) and post-ministerial occupation (once tenure ends). It is composed of 446 cabinet members, of which $31.3 \%$ are women, from the national governments operating in the period 2004-2011 in the following 22 countries: Australia, Austria, Belgium, Canada, Denmark, Finland, France, Germany, Greece, Iceland, Ireland, Italy, Japan, Luxembourg, Netherlands, New Zealand, Norway, Portugal, Spain, Sweden, Switzerland, and the United Kingdom. Presidents and prime ministers are excluded from the empirical analysis since they are the top executive selectors and have access to specific post-tenure options (Theakston and De Vries, 2012).

While information for the entire pool of aspirants and eligible candidates for legislative, executive and post-ministerial office does not exist, we can nonetheless focus on the individuals having obtained these positions and explore whether holding party office emerges as a relevant political capital resource in their selection or appointment. The elective (candidacy to legislative office) and appointed positions (cabinet inner portfolios and post-ministerial political positions) under examination are our dependent variables. They are all dichotomous variables taking value 1 for individuals having obtained such positions, and 0 otherwise (see appendix for details).

Our main independent variables are sex, with women taking value 1 and men taking value 0 , and party office. For candidacy to legislative office, building on CCS (2014), we have created a dichotomous variable which takes value 0 for candidates with no party office whatsoever, and 1 for candidates having held party office at any level (local, regional or national). For ministerial and post-ministerial appointments, Claveria's (2014a) database includes the dichotomous variable 'national party office'. Party office is more likely to be a key resource for ministerial and post-ministerial 
appointments if held at the national level, where the most attractive positions are usually distributed by political parties (Claveria and Verge, 2015: 823).

The distribution of party patronage is a formal prerogative of political parties but doing so to their loyal members is largely an informal (non written) practice. For this reason, the first step of the empirical analysis is to prove that party office matters in political recruitment processes. Secondly, to examine the interaction between this political capital resource and sex we run multivariate logistic regressions, wherein other control variables are added (for the description of variables see Appendix) and with errors clustered on country. To ease the interpretation of the interaction term we plot the predicted probability of obtaining each political position by party office and sex.

\section{Empirical analysis}

If party office is a political capital resource, holding such position should increase an individual's chance to get selected or appointed. Is this the case? As can be seen in Table 1, party office matters for all types of political recruitment, with differences being statistically significant in all sets of comparisons. Firstly, party service has been considered to be a "necessary apprenticeship before a party member is considered worthy of selection as a candidate" for legislative office (Henig and Henig, 2001: 48). Our results confirm that party service provides a comparative advantage to obtaining a candidacy. Among our sampled candidates competing in the most recent national legislative election, $80.3 \%$ held party office at any level - most of them (73.4\%) at the local level. ${ }^{1}$ In addition, among elected candidates, the percentage of individuals with party office raises to $92 \%$ while it remains steady for non-elected candidates $(80.3 \%)$.

Secondly, party office is also relevant for ministerial appointments. While the selection of ministers corresponds to prime ministers or presidents, top executive selectors follow some party criteria when making appointments, such as party geographical spread and factional diversity (Gómez and Verge, 2012). Likewise, service to the party and loyalty to the party leader set up opportunities for ministerial recruitment (Annesley, 2015: 637). Among our sampled cabinets, 27.4\% of ministers hold national party office. This percentage increases under generalist systems $(32.3 \%)-$ wherein ministers typically have broad parliamentary and political party backgrounds

\footnotetext{
${ }^{1}$ Even in the U.S, most of the state legislative candidates hold county or local office before they run for higher office (Crowder-Meyer, 2013: 395).
} 
rather than expert profiles - and decreases under specialist systems $(22.1 \%)$ - where ministers tend to be political outsiders (Davis, 1997).

As for type of portfolio, a few caveats are in order. Not all portfolios have the same value with variation found in the capacity to shape the cabinet's agenda, media exposure or parliamentary contact (Warwick and Druckman, 2001). Several classifications have been used to account for this variation: their more ('inner') or less ('outer') regular access to the president (Borrelli, 2002), their prestige in terms of budget and personnel (Escobar-Lemmon and Taylor Robinson, 2005), their focus on economic, central or social areas (Escobar-Lemon and Taylor-Robinson, 2014), or their stereotypically feminine, masculine or neutral policy domain (Davis, 1997). We concentrate on the inner-outer classification (Borrelli, 2002) because it facilitates crossnational comparisons. Inner portfolios (defense, treasury/economy, home office and foreign office) are found in every cabinet and in every country and do not tend to combine with other ministerial areas. Among our sampled cabinets, we find a relevant effect of party office on portfolio allocation: $34.5 \%$ of ministers in inner portfolios hold party office as compared with $24.2 \%$ of ministers in outer portfolios.

Thirdly, having this organizational resource pays off too for keeping active in public life once cabinet service ends. $31.8 \%$ of ex-ministers who get a new political position hold party office as compared to $21.5 \%$ who do not hold it. Given that under specialist systems long political careers are less frequent (Claveria and Verge, 2015), departing ministers staying active in the political field typically have party office in higher proportions (40\% versus $26.3 \%$ for other post-office occupations) than exministers getting new political positions under generalist systems $(26.1 \%$, as compared to $13.2 \%$ in other post-office occupations). In both cases, though, having this political resource is advantageous for obtaining a political post-office occupation.

\section{[TABLE 1 ABOUT HERE]}

Having proved that party office is a key political capital resource we move to assessing whether it operates in gendered ways, that is, whether its possession is more likely to benefit men more than women. 


\section{Candidacy to legislative office}

Among our 22 sampled countries, on average, the percentage of women in parliament where legislative quotas are not used is $30.6 \%$, a similar figure to that found where such measures are applied, 31.3\% - data from IPU as of July 1st, 2015. In none of these countries the stipulated minimum quota proportions for female candidates $(50 \%$ in Belgium and France, $40 \%$ in Spain, and 33\% in Greece and Portugal) have translated into equivalent percentages of women representatives. Lack of parity is not due to outright noncompliance with legislative quotas. Rather, the letter of the law is respected but its spirit is violated through the informal practice of gendered allocation of viable candidacy, as summarized in Figure 1 for the largest parties within these polities.

In Belgium, in the 2010 elections, although the share of men and female candidates was even (50\%), men headed $63 \%$ of lists and occupied $60 \%$ of winnable positions (IEFH, 2010). In Spain, in the 2011 elections, whereas men accounted for $53 \%$ of candidates, they occupied $59 \%$ of winnable positions and $66 \%$ of party lists were headed by men. In Portugal, in the 2011 elections, men represented $65 \%$ of candidates and obtained $72 \%$ of winnable positions and over $90 \%$ of top positions on lists (AUTHOR, 2016b). In Greece, in the June 2012 elections, men constituted 65\% of candidacies and were allotted $86 \%$ of winnable positions (Vassilakis, 2014: 9). In France, in the 2012 elections, men made for 60\% of candidates and largely outnumbered women in safe seats - e.g. in the Socialist Party $38 \%$ women candidates competed in safe districts as compared with 55\% men candidates (Murray, 2013: 203).

\section{[FIGURE 1 ABOUT HERE]}

While the CCS database (2014) does not include a variable specifying whether candidates ran in electable spots, we can use as a proxy the variable capturing whether the candidate was elected or not in the most recent national election. Political parties shape candidates' chances of getting elected through their assignment to either safe, competitive or hopeless seats - under plurality systems - or their rank order in electoral lists - under PR systems (Norris, 2004). Hence, being elected should be closely associated to having competed in a winnable position in party lists (PR) or in a safe seat (plurality). The share of party officeholders is similar among male (80.2\%) and female 
(79.6\%) candidates. Yet, how is the distribution of viable candidacy affected by possessing this organizational resource? While $88.3 \%$ of elected women held party office this was the case of $93.4 \%$ of men - difference significant at the $5 \%$ level.

As highlighted by Kolinsky (1993), long-term investment in party work is of paramount importance for obtaining a good position on party lists and thus having a greater chance of being elected. Table 2 shows that, prior to the most recent election, elected women had held local party office, on average, during 8.94 years as compared with 9.99 years in the case of elected men. This (non statistically significant) difference suggests that women are not required more seniority as (local) party officers to obtain an electable spot. However, strong gendered patterns emerge in the average monthly hours put into party work by elected candidates. Women devoted, on average, 72.97 hours whereas men devoted 48.24 hours. $^{2}$ This difference is statistically significant at the $1 \%$ level. This suggests that political parties have double standards when assigning viable candidacy across sex, with more demanding criteria being imposed on women.

\section{[TABLE 2 ABOUT HERE]}

The multivariate analysis further confirms the gendered patterns underpinning party office. The dependent variable takes value 1 for elected candidates and 0 for non elected candidates. Table 3 shows that, when controlling for party office and (logged) monthly hours, sex is still significant with a negative coefficient (Model 1). The two party-related variables increase candidates' chances of being elected. When the interaction term between sex and party office is added sex loses statistical significance (Model 2). The effect of party office on being elected - or, as we argue, on being placed on an electable position - is strong and significant for men (.845 coefficient) while for women is much weaker and non significant $\left(\beta_{\text {partyoffice }}-\beta_{\text {partyoffice*sex }}=.204\right)$. When the interaction is run between (logged) monthly hours of party work and sex (Model 3), we can see that for women to gain an electable spot they need to put longer hours ( $\beta_{\text {monthlyhours }}-\beta_{\text {monthlyhours*sex }}=.446$, versus .321 in the case of men). The last model includes the interactions between sex and the two party-related variables and adds

\footnotetext{
${ }^{2}$ Among non elected candidates no gender differences emerge. The much lower number of monthly hours of party work for these candidates (around 25 hours) reinforces the assumption that they were placed in non electable spots.
} 
educational level and age of candidates as controls (Model 4). The results are virtually the same, with the effect of party office for women further diminishing to an almost negligible impact. The marginal effect of party office is larger for men (.037) than for women (.0001) and is only statistically significant in the case of men.

\section{[TABLE 3 ABOUT HERE]}

As also illustrated in Figure 2a, holding or not holding party office does not affect at all women's predicted probability of being elected. Conversely, in the case of male candidates, their probability increases from $3.4 \%$ to $7.2 \%$. In regards to monthly hours of party work, as shown in Figure 2b, this investment pays off less to women than to men, unless long-hour workloads are reached. Female aspirants wishing to obtain an electable position must then work harder than their male peers. Therefore, our first hypothesis is confirmed (H1).

\section{[FIGURE 2 ABOUT HERE]}

\section{Ministerial recruitment and portfolio type}

In advanced industrial democracies, national governments included $28 \%$ women in the 2000s (Claveria, 2014b). To what extent do prime ministers and presidents, who are still overwhelmingly male, rely more on men than women when inviting officers from their national party leadership to join the cabinet? Female and male ministers are rather alike in holding national party office $-26.3 \%$ versus $30 \%$, respectively, with this difference not being statistically significant. Thus, we cannot accept our hypothesis H2.1. Yet, among the pool of ministers possessing this political capital resource, we find $66.1 \%$ men and $33.9 \%$ women, which suggests that either political parties supply cabinets with more male than female ministers or that top executive recruiters prefer their male copartisan over their female peers.

On the other hand, male dominance in the most prestigious portfolios is a global phenomenon (Borrelli, 2002; Davis 1997; Escobar-Lemmon and Taylor-Robinson, 2005; Krook and O'Brien, 2012). Whereas women account for $31.3 \%$ of ministers among our sampled cabinets, they only represent $18.9 \%$ of the holders of inner 
portfolios. Women ministers are distributed across portfolios in the following way: $18 \%$ are found in inner portfolios and $81 \%$ in outer portfolios, as compared with $35 \%$ and $65 \%$, respectively, in the case of men. Does portfolio allocation change when party office intervenes? $37.5 \%$ of women in inner portfolios hold national party office as compared with $34.3 \%$ of men in these portfolios, while in outer portfolios $28.3 \%$ of women possess this resource as compared with $21.9 \%$ of men. The difference is statistically significant only in the case of men - at the $5 \%$ level - so party office exclusively advantages male ministers.

Table 4 reports the results of the logistic regression for type of portfolio, which takes value 1 for inner portfolios and 0 for outer portfolios. The simplest model (Model 1) includes sex alongside national party office. Both variables are statistically significant and behave in the expected way, with party office increasing ministers' chances of being appointed to an inner portfolio and sex decreasing them. The interaction term between party office and sex suggests that party office yields a heterogeneous effect across sex that works to men's advantage (Model 2). This effect persists when several other factors are controlled for, such as seniority in public office, ${ }^{3}$ policy expertise in the purview of the portfolio and educational level (Model 3). The marginal effect of party office for men is quite strong (0.165) and statistically significant (at the 5\% level), while for women is much smaller (0.067) and non significant.

\section{[TABLE 4 ABOUT HERE]}

To further illustrate the extent to which men benefit more than women from holding a position in the national party leadership for obtaining an inner portfolio, we plot the predicted probabilities by sex. As can be seen in Figure 2c, men minister's probability of being appointed to such a portfolio when not holding party office is $32 \%$ and it climbs to $48.5 \%$ when party office is held. For women ministers, holding party office has a much weaker effect, as indicated by the rather flat line. Their probability of obtaining an inner portfolio increases marginally from $16.8 \%$ when not holding party

\footnotetext{
${ }^{3}$ Seniority correlates with age $(.381, \mathrm{p}<0.001)$, so age is not included in the model.
} 
office to $23.5 \%$ when this organizational resource is possessed. Hence, we can accept hypothesis $\mathrm{H} 2.2$.

\section{Post-ministerial occupation in politics}

Remaining in the core of politics (in the top echelons of the public administration, advisory and regulatory bodies or governing boards of public companies) is also more likely when national party office is held and the office-seeking politician is male. Among party officers, women represent $24 \%$ of departing ministers in new political positions and $44.4 \%$ of ex-ministers landing in other occupations - difference statistically significant at the 5\% level. When party office is not held, women exministers account for about $30 \%$ of individuals in both political and non-political postministerial occupations. So how does this political capital resource provide a differential advantage across sex groups? 33.6\% of men ex-ministers landing in another political office when cabinet service ends hold party office whereas among those not landing in new political positions only $18.0 \%$ hold party office - difference significant at the $1 \%$ level. In the case of women departing ministers the share of party officeholders is lower among those staying active in politics than among those starting other types of postoffice occupations (27.3\% versus $28.6 \%$ - non statistically significant).

The institutional configuration of post-ministerial occupation varies across types of ministerial recruitment (Claveria and Verge, 2015: 831). Under generalist systems, $28 \%$ of female ex-ministers landing in new political positions hold party office as compared with $21 \%$ of those who move elsewhere. In the case of men, party office makes a larger difference, with $25.6 \%$ of men ex-ministers who keep active in politics having this organizational resource vis-à-vis $10.5 \%$ of male departing ministers who start other post-ministerial occupations - statistically significant at the 5\% level. This differential effect broadens under specialist systems: the share of women having party office is lower among new political posts $(26.7 \%)$ than in non political post-ministerial occupations $(31.4 \%)$. In the case of men, party officeholders make for $48 \%$ of those newly recruited for politics and $23.2 \%$ of those occupying non political positions statistically significant at the $1 \%$ level.

The multivariate analysis further confirms that, like in the other stages of political recruitment, holding party office produces a heterogeneous effect by sex. Table 
5 presents the logistic regression for post-ministerial occupation, which takes value 1 for new political positions and 0 for other types of occupation. In the simplest model (Model 1), sex and party office are included as independent variables alongside countrylevel party patronage and type of political recruitment since this post-tenure option is much more frequent under generalist systems. All variables behave in the expected direction with only sex not reaching statistical significance. Sex and specialist systems diminish the probability of getting a new political position, whereas holding party office and higher levels of party patronage within the polity increase it. When the interaction between party office and sex is added, its large and negative coefficient - statistically significant at the $5 \%$ level - indicates that the positive effect of party office for female ex-ministers is canceled out (Model 2). Including the control variables policy expertise (positive but non significant coefficient) and seniority (positive coefficient) provides virtually the same results (Model 3). The marginal effect of party office for men is positive and strong (0.211) and statistically significant (at the 5\% level), while for women is negative $(-0.015)$ albeit non significant.

\section{[TABLE 5 ABOUT HERE]}

Figure $2 \mathrm{~d}$ plots the predicted probabilities of landing in new political positions by party office and sex. In the case of men, ex-ministers with party office are much more likely to continue their political career upon termination of cabinet service than those lacking this political capital resource, with their probability boosting from $42.5 \%$ to $63.6 \%$. In sharp contrast, for female departing ministers, experience in national party office provides no comparative advantage - with their probability even slightly decreasing, from $48.3 \%$ to $46.7 \%$. Consequently, party office exclusively expands men's post-tenure options in politics, which corroborates our third hypothesis (H3).

This sex-segregated reward system is not shaped by women ministers' lower departmental performance. Indeed, exiting the cabinet for this reason presents a similar occurrence for male and female ministers $-25 \%$ and $27 \%$ of reshuffled ministers, respectively. Furthermore, no female minister left the cabinet due to sexual or corruption scandals - this only affected $10 \%$ of reshuffled men ministers. Other reasons for exiting the cabinet do present, though, strong gendered patterns: whereas the most 
common reason for men is having obtained another office within or outside the government (35\%, versus $19 \%$ for women), for women it is dismissal, that is forced resignation in a general context of cabinet reshuffle (54\%, versus $31 \%$ for men). This may indicate that female ministers are absent from presidents' inner circles of confidence, since they are much more likely to be let go than male ministers (see also Escobar-Lemmon and Taylor-Robinson, 2015).

\section{Conclusions}

Party office has been shown to be a key political capital resource providing those seeking a political career with privileged access to the distribution of public positions but it turns out to operate in gendered ways since it mostly benefits men. Holding party office pays off more to male candidates than to female candidates in obtaining an electable spot in legislative elections. Women also need to put longer hours in party work to be rewarded with such positions. Among the pool of ministers holding party office men clearly outnumber women and have a much higher probability to be appointed to inner portfolios. And possessing this political capital resource exclusively helps male departing ministers obtain new political positions. These findings are informative for both party politics and gender and politics scholars. Gender differences in the benefits carried by party office fundamentally confirm the genderedness of party organizations and present a paradox for internal party democracy.

While we have proven that advantage and disadvantage within parties is patterned through gender in all types of political recruitment, further research is needed to shed light on its specific operation. As has been already outlined, only some offices within the party leadership may propel political careers, with men being overrepresented in such offices (Threlfall, 2005; Verge and de la Fuente, 2014). Simultaneously, women might "not have gained power relative to where power lies" (Childs, 2013: 93). Rather, male informal networks may still control the party patronage entitlements and use them to reward network members - i.e. men (see, among others, Annesley, 2015; Cheng and Tavits, 2011). Since interpersonal relationships are riddled with sex-role ideology and gendered stereotypes about behaviors, styles, and attitudes (Kelly and Duerst-Lahti, 1995: 59), the likeability and understanding derived from such male "homosocial capital" (Bjarnegård, 2013) may translate into top selectors relying more on other men. 
Therefore, in order to unveil which factors make party office more valuable when held by men than by women, scholars should delve into the gendered informal norms and practices that lie behind political recruitment processes specifically and that underpin party politics more generally (Bjarnegård and Kenny, 2015). A feminist institutionalist approach, one delving into the gendered dimensions of the opportunity structures within institutions (see Chappell and Waylen, 2013; Mackay, Kenny and Chappell, 2010), is a fruitful avenue to uncover the extent to which gender power dynamics within political parties are capable of subordinating or empowering individuals with similar party positional power and to identify the precise ways through which they are manifested.

\section{References}

Annesley, C (2015) Rules of Ministerial Recruitment. Politics \& Gender 11(4): 618-42. Annesley, C and Gains, F (2010) The Core Executive: Gender, Power and Change. Political Studies 58(5): 909-29.

AUTHOR (2016a) Opening Up the Black Box: Gender and Candidate Selection in a New Era. Government and Opposition 51 (3) (in press).

AUTHOR (2016b) Interactions between Party and Legislative Quotas: Candidate Selection and Quota Compliance in Portugal and Spain. Government and Opposition 51 (3) (in press).

Bashevkin, S (2010) When do outsiders break in? Institutional circumstances of party leadership victories by women in Canada. Commonwealth \& Comparative Politics 48(1): 72-90.

Bjarnegård, E (2013) Gender, Informal Institutions and Political Recruitment. Explaining Male Dominance in Parliamentary Representation. Basingstoke: Palgrave Macmillan.

Bjarnegård, E and Kenny, M (2015) Revealing the 'secret garden': The informal dimensions of political recruitment. Politics \& Gender 11(4): 748-53.

Blondel, J (2000) A Framework for the Empirical Analysis of Government-Supporting Party Relationships. In J Blondel and M Cotta (eds), The Nature of Party Government. A Comparative European Perspective. New York: Palgrave, pp. 96116. 
Borrelli, MA (2002) The President's Cabinet: Gender, Power, and Representation. Boulder: Lynne Rienner.

CCS (2014) Comparative Candidates Survey Module I - 2005-2012 [Dataset cumulative file]. Distributed by FORS, Lausanne, 2014.

Claveria, S (2014a). Women in executive office in advanced industrial democracies: Presence, portfolios and post-ministerial occupation. $\mathrm{PhD}$ dissertation. Barcelona: Universitat Pompeu Fabra.

Claveria, S (2014b) Still a 'Male Business'? Explaining Women's Presence in Executive Office. West European Politics 37(5): 1156-176.

Claveria, S and Verge, T (2015) Post-ministerial Occupation in Advanced Industrial Democracies: Ambition, Individual Resources and Institutional Opportunity Structures. European Journal of Political Research 54(4): 819-35.

Chappell, L and Waylen, G (2013) Gender and the Hidden Life of Institutions. Public Administration 91(3): 599-615.

Cheng, C and Tavits, M (2011) Informal Influences in Selecting Female Political Candidates. Political Research Quarterly 64(2): 460-71.

Childs, S (2013) Intraparty Democracy: A gendered critique and a feminist agenda. In W Cross and R Katz (eds.), The Challenges of Intra-Party Democracy. Oxford: Oxford University Press, pp. 81-99.

Childs, S and Murray, R (2014) Feminising political parties. In R Campbell and S Childs (eds.), Deeds and words: Gendering politics after Joni Lovenduski. Colchester: ECPR Press, pp. 73-90.

Crowder-Meyer, M (2013) Gendered Recruitment without Trying: How Local Party Recruiters Affect Women's Representation. Politics \& Gender 9(4): 390-413.

Davis, RH (1997) Women and power in parliamentary democracies: Cabinet appointments in Western Europe, 1968-1992. Lincoln: University of Nebraska Press.

Escobar-Lemmon, $M$ and Taylor-Robinson, M (2005) Women Ministers in Latin American Government: When, Where, and Why?. American Journal of Political Science 49(4): 829-44.

Escobar-Lemmon, M and Taylor-Robinson, M (2008) How do candidate recruitment and selection processes affect the representation of women?. In PM. Siavelis and S 
Morgenstern (eds), Pathways to power: Political recruitment and candidate selection in Latin America. Pennsylvania: Pennsylvania State University Press, pp. 345-68.

Escobar-Lemmon, M and Taylor-Robinson, M (2014) Who You Know, What You Know or Who You Are? Does Background Trump Gender in Consistent Way in Cabinet Appointments?. Paper prepared for ECPR Joint Sessions. Salamanca, April 10-15.

Escobar-Lemmon, M and Taylor-Robinson, M (2015) Sex, Survival, and Scandal: A Comparison of How Men and Women Exit Presidential Cabinets. Politics \& Gender 11(4): 665-88.

Fowlkes, DL, Perkins, J and Tolleson Rinehart, S (1979) Gender Roles and Party Roles. American Political Science Review 73(3): 772-80.

Franceschet, S and Piscopo, J (2014) Sustaining Gendered Practices? Power and Elite Networks in Argentina. Comparative Political Studies 47(1): 85-110.

Franceschet, S and Thomas, G (2015) Resisting Parity: Gender and Cabinet Appointments in Chile and Spain. Politics \& Gender 11(4): 643-64.

Gallagher, M and Marsh, M (1988) Candidate selection in comparative perspective: The Secret Garden of Politics. London: Sage.

Gómez, R and Verge, T (2012) Party patronage in Spain: Appointments for party government. In P Kopecký, P Mair and M Spirova (eds), Party Patronage and Party government in European democracies. Oxford: Oxford University Press, pp. $316-34$.

Henig, R and Henig, S (2001). Women and political power: Europe since 1945. London: Routledge.

IPU (2015). Database Women in Parliaments. http://ipu.org/wmn-e/classif.htm

IEFH (2010). La participation politique des femmes en politique à l'issue des élections du 13 juin 2010. Brussels: Institut pour l'Égalité des Femmes et des Hommes.

Jennings, MK and Farah, BG (1981) Social Roles and Political Resources: An OverTime Study of Men and Women in Party Elites. American Journal of Political Science 25(3): 462-82.

Karam, A and Lovenduski, J (2005) Women in parliament: Making a difference. In J Ballington and A Karam (eds), Women in parliament: Beyond numbers. Stockholm: International IDEA, pp. 187-213. 
Kelly, RM and Duerst-Lahti, G (1995) The study of gender power and its link to governance and leadership. In G Duerst-Lahti and RM Kelly (eds), Gender power, leadership, and governance. Ann Arbor: University of Michigan Press, pp. 39-64.

Kittilson, MC (2006) Challenging parties, changing parliaments. Women and elected effice in contemporary Western Europe. Columbus: The Ohio State University Press.

Kittilson, MC (2013) Party politics. In G Waylen, K Celis, J Kantola and SL Weldon (eds), The Oxford handbook of gender and politics. Oxford: Oxford University Press, pp. 536-53.

Krook, ML and O'Brien, DZ (2012) All the President's Men? The Appointment of Female Cabinet Ministers Worldwide. The Journal of Politics 74(3): 840-55.

Kolinsky, E (1993) Party change and women's representation in Unified Germany. In J Lovenduski and P Norris (eds.), Gender and party politics. London: Sage, pp. $113-46$.

Kopecký, P and Mair, P (2012) Party patronage as an organizational resource. In P Kopecký, P Mair and M Spirova (eds), Party patronage and party government in European democracies. Oxford: Oxford University Press, pp. 3-16.

Kunovich, S and Paxton, P (2005) Pathways to Power: The Role of Political Parties in Women's National Political Representation. American Journal of Sociology 111(2): 505-52.

Lovenduski, J (2005) Feminizing politics. Cambridge: Polity Press.

Mackay, F, Kenny, M and Chappell, L (2010) New Institutionalism Through a Gender Lens: Towards a Feminist Institutionalism?. International Political Science Review 31(5): 573-88.

Müller, WC (2006). Political institutions and linkage strategies. In H Kitschelt and SI Wilkinson (eds), Patrons, clients and policies. Patterns of democratic accountability and political competition. Cambridge, MA: Cambridge University Press, pp. 251-75.

Murray, R (2013) Towards Parity Democracy? Gender in the 2012 French Legislative Elections. Parliamentary Affairs 66(1): 197-212. 
Nicholls, K (1991) The Dynamics of National Executive Service: Ambition Theory and of the Careers of Presidential Cabinet Member. Western Political Quarterly 44(1): $149-72$.

Niven, D (1998). Party Elites and Women Candidates: The Shape of Bias. Women and Politics 19(2): 57-80.

Norris, P (2004) Electoral engineering. Cambridge: Cambridge University Press.

O'Brien, DZ (2015) Rising to the Top: Gender, Political Performance, and Party Leadership in Parliamentary Democracies. American Journal of Political Science. doi: 10.1111/ajps.12173

O’Brien, DZ and Rickne, J (2014) Gender Quotas and Women's Political Leadership. IFN Working Paper No. 1043. Stockholm: Research Institute of Industrial Economics.

O’Neill, B and Stewart, DK (2009) Gender and Political Party Leadership in Canada. Party Politics 15(6): 737-57.

Scarrow, SE and Gezgor, B (2010) Declining Memberships, Changing Members? European Political Party Members in a New Era. Party Politics 16(6): 823-43.

Shea, DM and Harris, RC (2006) Gender and Local Party Leadership. Journal of Women, Politics and Policy 28(12): 61-85.

Trimble, L and Arscott, J (2003) Still counting: Women in politics across Canada. Peterborough: Broadview.

Theakston, K and De Vries, J (eds) (2012) Former leaders in modern democracies.

London: Palgrave.

Threlfall, M (2005) Towards parity representation in party politics. In M Threlfall, C Cousins and C Valiente (eds), Gendering Spanish democracy. New York: Routledge, pp. 125-61.

Vassilakis, A (2014) The Greek Elections of 2012: The Impact of Closed and Open Electoral Systems on Female Candidates. The AHIF Policy Journal 5 (Spring 2014): 1-24.

Verge, T (2015) The Gender Regime of Political Parties: Feedback Effects between Supply and Demand. Politics \& Gender 11(4): 754-59. 
Verge, T and de la Fuente, M (2014) Playing with Different Cards: Party Politics, Gender Quotas and Women's Empowerment. International Political Science Review 35(1): 67-79.

Warwick, PV and Druckman, JN (2001) Portfolio Salience and the Proportionality of Payoffs in Coalition Governments. British Journal of Political Science 31(4): $627-49$.

Wauters, B and Pilet, JB (2015) The selection of female party leaders. Does the selectorate make a difference?. In W Cross and JB Pilet (eds), The politics of party leadership: A cross-national perspective. Oxford: Oxford University Press, pp. 73-89. 


\section{Appendix. Data sources and variables}

\section{Comparative Candidate Survey (CCS, 2014)}

A4a1. Stood as a candidate in most recent national election: Yes/No

*A4b1. Elected in the most recent national election: Yes/No

$A 8 a$. How many years local party office

$A 8 b$. How many years regional party office

$A 8 c$. How many years national party office

A12. Number of hours devoted to party activities in an average month

E1. Gender

E2. Year of birth

E6a. Level of education (1=Incomplete primary; 2=Primary completed; 3=Incomplete secondary; 4=Secondary completed; 5=Post secondary trade/vocational school; 6=University incomplete; $7=$ University completed)

\section{Cabinet ministers (Claveria, 2014a)}

*Type of portfolio (inout2): 1=Inner portfolios (defense, treasury/economy, home office and foreign office); $0=$ Outer portfolios (remaining portfolios).

*Post-ministerial occupation (post_pol2): 1=Politics, such as positions in the top echelons of the public administration, advisory and regulatory bodies and governing boards of public or recently privatized companies; $0=$ Other post-office occupations including ministerial reappointments).

Sex: $1=$ Women; $0=$ Men.

Party office (partys): 1=Ministers holding or having held national party office (sitting members of national executive bodies) before or during their tenure in cabinet; $0=$ otherwise.

Seniority: Number of years a minister accumulates in any (appointed or elective) public office at any tier of government prior to cabinet entry.

Policy expertise (ink_estmin): 1=Ministers having university education or previous (nonpolitical) professional experience in the purview of their portfolio; $0=$ Otherwise.

Educational level (edu3): 1=Primary education; 2=Secondary education; 3=Tertiary education.

Ministerial recruitment (v41): $1=$ Specialist systems; $0=$ Generalist systems.

Patronage level (patronagedum): 1=High or medium levels; $0=$ Low levels or virtually none.

* Dependent variables.

Replication do files will be made available at the authors' website. 


\section{Tables and Figures}

Table 1 . The benefits of party office

\begin{tabular}{lcc}
\hline Parliamentary candidacy & Elected candidates & $92.0 \% * * *$ \\
& Non-elected candidates & $80.3 \%$ \\
\hline \multirow{2}{*}{ Ministerial recruitment } & Generalist systems & $32.3 \% *$ \\
& Specialist systems & $22.1 \%$ \\
& Inner ministries & $34.5 \% *$ \\
& Outer ministries & $24.2 \%$ \\
\hline Post-ministerial occupation & Politics & $31.8 \% *$ \\
& Other & $21.5 \%$ \\
& Specialist - Politics & $40.0 \% *$ \\
& Specialist - Other & $26.3 \%$ \\
& Generalist - Politics & $26.0 \% *$ \\
\hline
\end{tabular}

Notes: Party office held at any level for parliamentary candidacy and at the national level for ministerial and post-ministerial positions.

$* 0.05 ; * * 0.01 ; * * * 0.001$. 
Table 2. Party service and legislative elections

\begin{tabular}{lccr}
\hline Candidates & Sex & Years in local party office & \multicolumn{1}{l}{$N$} \\
\hline Non elected & Men & $6.40(8.54)$ & 4680 \\
& Women & $5.66(7.11)$ & 2641 \\
Elected & Men & $9.99(10.63)$ & 379 \\
& Women & $8.94(8.97)$ & 154 \\
\hline \multirow{2}{*}{ Non elected } & Sex & Monthly hours of party work & \multicolumn{1}{c}{ ( } \\
& Men & $25.82(47.14)$ & 4550 \\
\multirow{2}{*}{ Elected } & Women & $25.63(40.75)$ & 2524 \\
& Men & $48.24(76.28)$ & 341 \\
& Women & $72.97(98.67) * *$ & 143 \\
\hline
\end{tabular}

Standard errors in parentheses.

$0.01 * *$ 
Table 3. The determinants of viable candidacy

\begin{tabular}{|c|c|c|c|c|}
\hline & Model 1 & Model 2 & Model 3 & Model 4 \\
\hline \multirow[t]{2}{*}{ Sex (Women=1) } & $-.278 * *$ & .299 & -.678 & .063 \\
\hline & $(.107)$ & $(.330)$ & $(.480)$ & $(.448)$ \\
\hline \multirow[t]{2}{*}{ Party office (any) } & $.626 * *$ & $.845 * *$ & $.625 * *$ & $.792 * *$ \\
\hline & $(.212)$ & $(.289)$ & $(.211)$ & $(.303)$ \\
\hline \multirow[t]{2}{*}{ Monthly hours (logged) } & $.356 * * *$ & $.357 * * *$ & $.321 * *$ & $.328 * *$ \\
\hline & $(.100)$ & $(.100)$ & $(.115)$ & $(.123)$ \\
\hline \multirow[t]{2}{*}{ Sex*Party office } & & $-.641 *$ & & $-.789 *$ \\
\hline & & $(.328)$ & & $(.369)$ \\
\hline \multirow[t]{2}{*}{ Sex*Monthly hours } & & & .125 & .156 \\
\hline & & & $(.133)$ & $(.138)$ \\
\hline \multirow[t]{2}{*}{ Educational level } & & & & $.266 *$ \\
\hline & & & & $(.135)$ \\
\hline \multirow[t]{2}{*}{ Age } & & & & $.033 * *$ \\
\hline & & & & $(.011)$ \\
\hline \multirow[t]{2}{*}{ Constant } & $-4.233 * * *$ & $-4.436 * * *$ & $-4.121 * * *$ & $-7.705 * * *$ \\
\hline & $(.239)$ & $(.311)$ & $(.289)$ & (1.143) \\
\hline Observations & 6532 & 6532 & 6532 & 4812 \\
\hline Number of clusters & 11 & 11 & 11 & 10 \\
\hline Pseudo $\mathrm{R}^{2}$ & .0354 & .0364 & .0360 & .0766 \\
\hline
\end{tabular}

Notes: Logistic regression. DV: Elected in most recent election (1), Non elected in most recent election (0). Model 4 includes just 10 countries because Sweden has missing data for the control variable 'age'.

Standard errors in parentheses.

${ }^{+} 0.1 ; * 0.05 ; * * 0.01 ; * * * 0.001$. 
Table 4. The determinants of portfolio allocation

\begin{tabular}{lccc}
\hline & Model 1 & Model 2 & Model 3 \\
\hline Sex (Women=1) & $-.913^{* * *}$ & $-.843^{*}$ & $-.865^{*}$ \\
& $(.345)$ & $(.345)$ & $(.368)$ \\
Party office (national level) & $.569^{*}$ & $.620^{*}$ & $.717^{*}$ \\
Women*Party office & $(.326)$ & $(.323)$ & $(.325)$ \\
& & -.201 & -.284 \\
Seniority & & $(.615)$ & $(.741)$ \\
& & & $.028^{* *}$ \\
Policy expertise & & & $(.008)$ \\
& & & .163 \\
Educational level & & & $(.244)$ \\
& & & $.452^{*}$ \\
Constant & & & $(.211)$ \\
\hline Observations & $-.764^{* * *}$ & $-.778^{* * *}$ & $-1.760^{* * *}$ \\
Number of clusters & $(.162)$ & $(.160)$ & $(.407)$ \\
Pseudo R & 419 & 419 & 359 \\
\hline
\end{tabular}

Notes: Logistic regression. DV: Inner portfolio (1); Outer portfolio (0). Standard errors in parentheses. ${ }^{+} 0.1 ; * 0.05 ; * * 0.01 ; * * * 0.001$. 
Table 5. The determinants of post-ministerial occupation

\begin{tabular}{lccc}
\hline & Model 1 & Model 2 & Model 3 \\
\hline Sex (Women=1) & -.066 & .224 & .260 \\
Party office (national level) & $.235)$ & $(.326)$ & $(.345)$ \\
& $.706^{*}$ & $1.062^{* *}$ & $.945^{*}$ \\
Women*Party office & & $(.427)$ & $(.423)$ \\
& & $-1.059^{*}$ & $-1.015^{+}$ \\
Seniority & & $(.519)$ & $(.534)$ \\
& & & $.028^{+}$ \\
Policy expertise & & & $(.014)$ \\
& & & -.210 \\
Specialist systems & $-1.039 * *$ & $-1.070 *$ & $-1.010^{*}$ \\
Patronage level & $.458)$ & $(.431)$ & $(.446)$ \\
& .220 & .201 & .194 \\
\hline Constant & $(.521)$ & $(.474)$ & $(.468)$ \\
\hline Observations & .196 & .133 & -.200 \\
Number of clusters & $(.521)$ & $(.533)$ & $(.625)$ \\
Pseudo R & & & 400 \\
\hline
\end{tabular}

Notes: Logistic regression. DV: Post-ministerial occupation in politics (1), Other occupations (0). Ministers retiring right after leaving the cabinet are excluded from the analysis.

Standard errors in parentheses. ${ }^{+} 0.1 ; * 0.05 ; * * 0.01 ; * * * 0.001$. 
Figure 1. Men in party lists (\%) - Average for the largest political parties

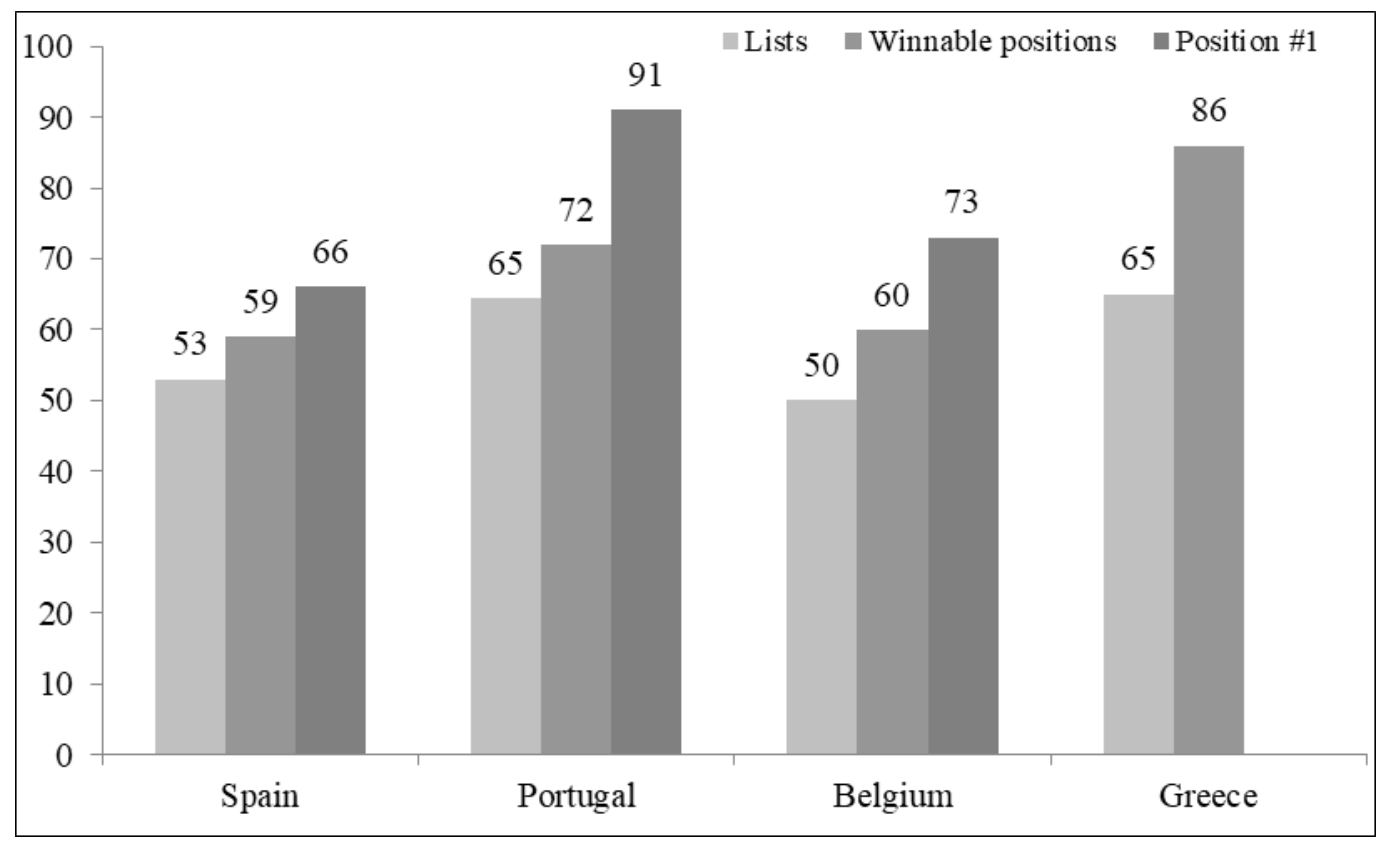

Own elaboration based on AUTHOR (2016b), IEFH (2010) and Vassilakis (2014). Legislative elections held in 2011 in both Spain and Portugal, 2010 in Belgium, and 2012 (June) in Greece. Parties included: PSOE and PP, in Spain; PS and PSD, in Portugal; PASOK, ND, Syriza, KKE, Golden Dawn, Independent Greeks and Democratic Left, in Greece; NVA, CD\&V, MR and PS, in Belgium. Data on the gender distribution of position number one is not available. 
Figure 2. Predicted probability by party office and sex (95\% CI)
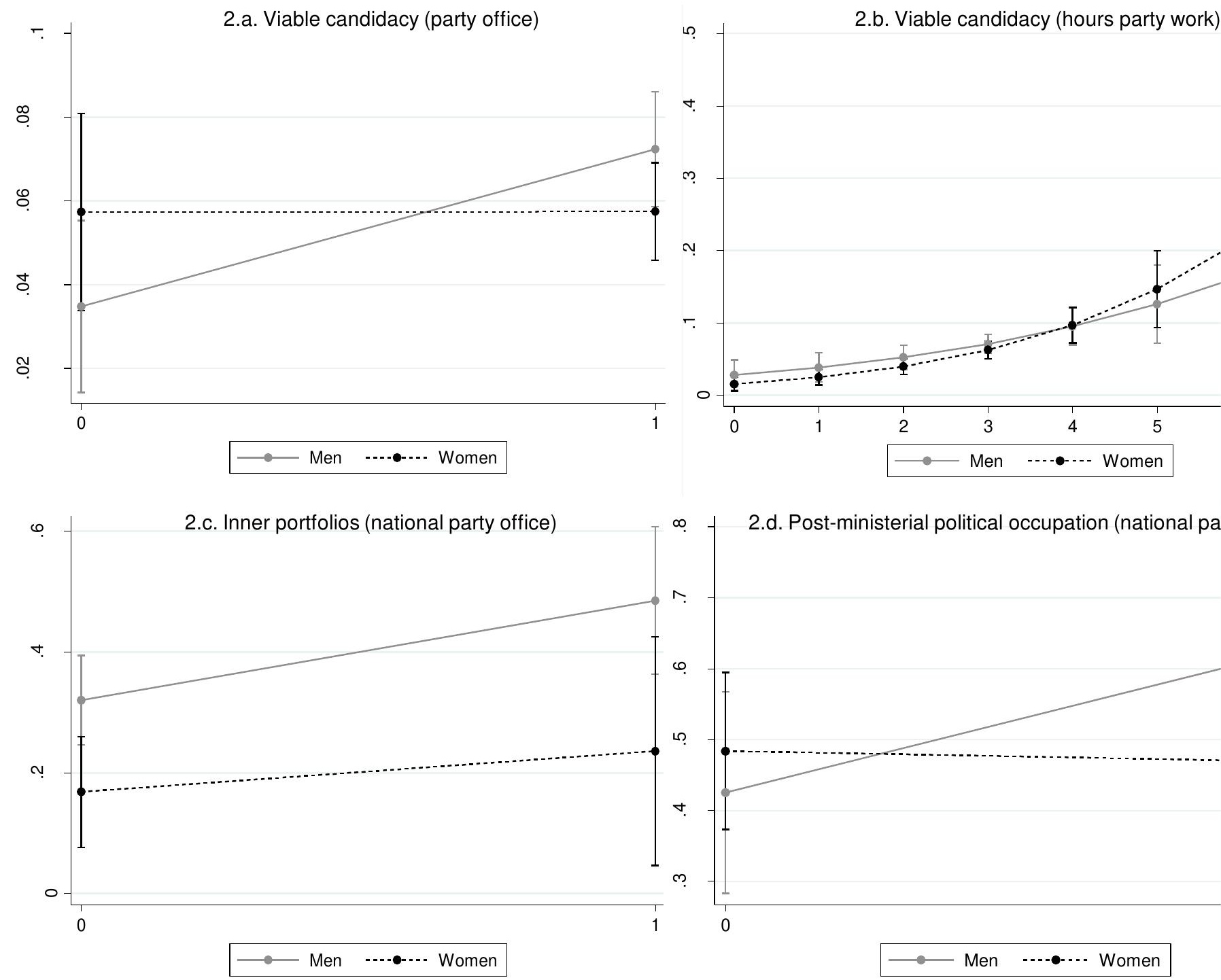